Eur J Clin Chem Clin Biochem

1995; 33:5-9

(C) 1995 Walter de Gruyter \& Co.

Berlin · New York

\title{
Serum Lipoprotein Changes after Orchidectomy and Treatment with Oestrogens and Luliberin Analogues in Male Sprague-Dawley Rats
}

\author{
By C. Lladó-Carbonell ${ }^{1}$, M. Senti-Clapes ${ }^{2}$, J. Rubiés-Prat ${ }^{2}$, O. Arango-Toro ${ }^{1}$ and A. Gelabert-Mas ${ }^{1}$ \\ 1 Departament d'Urologia \\ 2 Departament d'Medicina \\ Hospital del Mar, Universitat Autònoma de Barcelona, Institut Municipal d'Investigació Mèdica, Barcelona, Spain
}

(Received August 1/November 8, 1994)

Summary: The effect of androgen deprivation on lipoprotein profile and cardiovascular risk in men with advanced prostatic carcinoma is a matter of controversy. We describe an experimental model to evaluate the effects of orchidectomy and oestrogen and luliberin analogue administration on lipoprotein profiles in male Sprague-Dawley rats. Eighty rats were divided into three treatment groups and a control group. Results were compared with the scanty human data found in the literature. The oestrogen group was that which showed more differences compared with the control group, but its lipoprotein profile differed from that obtained in humans. Orchidectomy and luliberin analogue groups showed fewer differences than the oestrogen group, but a non-favourable lipoprotein profile in terms of cardiovascular risk was observed. There were important differences between humans and rats with regard to lipoprotein profile, suggesting that rats are probably not a good model for the study of atherogenic risk.

\section{Introduction}

Androgen deprivation was introduced over 50 years ago by Huggins \& Hodges (1) for the treatment of prostatic carcinoma. This effective mode of treatment is administered in almost all cases of prostatic cancer considered to be surgically incurable. Orchidectomy, oestrogens and luliberin analogues are effective tools for hormone treatment in advanced disease, and are used interchangeably according to patient or physician preferences since their clinical effects are similar in patients with hormone-sensitive prostatic cancer (2). These three forms of androgen deprivation therapy act at different levels in the metabolic pathway of androgen synthesis and lipoprotein metabolism which change plasma lipoprotein profile. Nowadays, prostatic carcinoma is perhaps the most frequent cancer in men with an incidence that increases with age parallel to that of cardiovascular disease. Thus, we presupposed that hormone treatment, depending on its level of interference and lipoprotein changes, might influence the risk of atherosclerotic cardiovascular disease $(3-5)$.
The effect of steroid hormones on lipoprotein metabolism described in extensive studies on oral contraceptives and oestrogen replacement therapy in postmenopausal women are well known (6), but have scarcely been studied in men, bearing in mind the differences in plasma lipoprotein patterns between men and women. Orchidectomy was the first mode of androgen deprivation (1) and luliberin analogues have recently been introduced in the treatment of prostatic carcinoma $(7,8)$. Several authors have described their effects on plasma lipoprotein profiles in men with advanced prostatic carcinoma, but most of these studies were incomplete and not randomized $(5,9-12)$.

Although lipoprotein metabolism in rats can not be extrapolated to humans, the aim of the present study was to investigate the effects of orchidectomy, oestrogen administration and luliberin analogue therapy on lipoprotein profiles in rats. To our knowledge, experimental studies on plasma lipoprotein profiles following androgen deprivation in Sprague-Dawley rats have not been previously reported. 


\section{Materials and Methods}

Animals

Four groups of 20 male Sprague-Dawley rats (Oncins France Strain A-OFA rat-Prolabor Laboratorios. Barcelona, Spain) aged from 6-8 weeks with a body weight of $200-275 \mathrm{~g}$. were studied.

\section{Control group}

Twenty rats were kept in metabolic cages with an homogeneous and regular diet of standard Pecoris rat chow (Prolabor Laboratorios) and water ad libitum for eight weeks. They were then fasted for eight hours, weighed and anaesthetized with ketamine $250 \mathrm{mg}$ $(2.5 \mathrm{ml})+$ diacepam $20 \mathrm{mg}(4 \mathrm{ml})+$ atropine $1 \mathrm{mg}(1 \mathrm{ml})$ at a dose of $0.5 \mathrm{ml} / 100 \mathrm{mg}$ of weight (i. m.). Middle laparotomy was performed, a catheter inserted in the aorta artery and all its blood drawn for testosterone and lipoprotein analysis.

Lipoprotein analysis was performed by processing blood samples by centrifugation at $3000 \mathrm{~min}^{-1}$ for $10 \mathrm{~min}$. The serum obtained was used to measure testosterone levels, serum cholesterol, serum triacylglycerols, cholesterol, triacylglycerols and proteins in very low density lipoproteins (VLDL), intermediate density lipoproteins (IDL), low density lipoproteins (LDL) and high density lipoproteins (HDL). V:LDL fraction $\left(\mathrm{d}<1.006 \mathrm{~kg} / \mathrm{dm}^{3}\right)$ was isolated by preparative ultracentrifugation in a Centrikon ultracentrifugal (Kontron Instruments, Milan, ltaly) using a TFT 50.38 rotor (Kontron Instruments). The remaining lipoproteins (IDL: 1.006 $<\mathrm{d}<1.019 \mathrm{~kg} / \mathrm{dm}^{3} ;$ LDL: $1.019<\mathrm{d}<1.063 \mathrm{~kg} / \mathrm{dm}^{3}$; and HDL: $\mathrm{d}>1.063 \mathrm{~kg} / \mathrm{dm}^{3}$ ) were isolated by density gradient ultracentrifugation in a TST 41.14 rotor. Serum cholesterol, serum triacylglycerols, cholesterol and triacylglycerols of lipoprotein fractions were measured enzymatically using a selective multichannel analyzer Eris (Eppendorf, Hamburg, Germany) and standardized with control sera (Qualitrol, Merck, Frankfurt, Germany). Proteins of each isolated fraction were determined by a colorimetric method.

\section{Orchidectomy group}

Twenty rats were kept in metabolic cages with an homogeneous and regular diet of standard Pecoris rat chow (Prolabor Laboratorios) and water ad libitum for one week to become adapted. They were then weighed, and anaesthetized following the protocol described above, and bilateral orchidectomy was performed. The rats were kept in metabolic cages in the same conditions for a further seven weeks, being weighed, fasted for eight hours and blood samples obtained as before for testosterone (in all samples at levels of castration $<0.2 \mu \mathrm{g} / \mathrm{l}$ ) and lipoprotein analysis.

\section{Oestrogens group}

Twenty rats were kept in metabolic cages with an homogeneous and regular diet of standard Pecoris rat chow (Prolabor Laboratorios) and water ad libitum for one week to become adapted. They were then injected subcutaneously with fosfestrol (stilboestrol diphosphate, Honvan ${ }^{\circledR}$ ) $3 \mathrm{mg} / \mathrm{kg}$ daily for five weeks, being weighed, fasted for eight hours and blood samples obtained as before for testosterone (in all samples at levels of castration $<0.2 \mu \mathrm{g} / \mathrm{l}$ ) and lipoprotein analysis. Fosfestrol was chosen for this study because of its use in clinical practice at our Department.

\section{Luliberin analogue group}

Twenty rats were kept in metabolic cages with an homogeneous and regular diet of standard Pecoris rat chow (Prolabor Laboratorios) and water ad libitum for one week to become adapted. They were then injected subcutaneously with triptoreline (Decapeptyl ${ }^{\circledR}$ ) $300 \mu \mathrm{g} / \mathrm{kg}$ every 28 days for eight weeks (two doses), being weighed, fasted for eight hours and blood samples obtained as before for testosterone (in all samples at levels of castration $<0.2$ $\mu \mathrm{g} / \mathrm{l})$ and lipoprotein analysis. Triptoreline was chosen for this study because of its use in clinical practice at our Department.

\section{Statistical analysis}

Normal distribution of continuous variables was confirmed by the Kolmogorov-Snirnoff test. Inter-group comparison was made by analysis of variance used factorially, and intra-group differences were tested by the Fisher PLSD test.

\section{Results}

Serum cholesterol and triacylglycerols and cholesterol, triacylglycerols and proteins in VLDL, IDL, LDL and $\mathrm{HDL}$ are shown in table 1 . Significant differences were observed in serum cholesterol $(p<0.0001)$, for which the oestrogen group showed a statistically significant decrease compared with the other groups $(p<0.05)$. Likewise, the luliberin analogue group showed an increase in serum cholesterol versus the control group $(p<0.05)$. Significant differences were observed in VLDL-cholesterol $(p<0.042)$, with a fall in the oestrogen group compared with the control group $(p<0.05)$. Significant differences were also found in IDL-cholesterol $(p<0.0001)$, with increases in all three treatment groups versus the control group $(p<0.05)$. IDL-proteins showed significant differences $(p<0.0128)$, with increases in the orchidectomy group versus the control and oestrogen groups $(p<0.05)$. LDL-cholesterol showed significant differences $(p<0.0038)$, with increases in the luliberin analogue group versus the control and oestrogen groups $(p<0.05)$, and the orchidectomy group versus the oestrogen group $(p<0.05)$. Significant differences were also observed in LDL-proteins ( $p<0.001$ ), with increases in the orchidectomy and luliberin analogue groups compared with the control and oestrogen groups $(p<0.05)$. HDL-cholesterol showed significant differences $(p<0.0001)$, with a large fall in the oestrogen group versus all the other groups $(p<0.05)$. HDL-proteins showed significant differences $(p<0.0001)$, with a large increase in the oestrogen group versus the other three groups $(p<0.05)$, and increases in the orchidectomy group versus the control group $(p<0.05)$.

\section{Discussion}

Serum lipoprotein composition in rats differs significantly according to the rat strain. Furthermore, the finding of great variations in lipoprotein composition in animals of the same strain is noteworthy. These discrepancies are difficult to explain solely on the basis of nutritional status, and are probably related to pooling of small blood samples from several animals $(13-16)$. This drawback was obviated in the present study since lipo- 
Tab. 1 Lipoprotein values. The results are given as mean \pm SD mmol/l (lipids) and $\mathrm{g} / \mathrm{l}$ (proteins).

\begin{tabular}{|c|c|c|c|c|c|}
\hline Serum & Control & Orchidectomy & Oestrogens & Luliberin & $\mathrm{p}$ \\
\hline $\begin{array}{l}\text { Cholesterol } \\
\text { Triacylglycerols }\end{array}$ & $\begin{array}{l}2.13(0.45) \\
1.21(0.81)\end{array}$ & $\begin{array}{l}2.38(0.59) \\
1.24(0.74)\end{array}$ & $\begin{array}{l}1.02(0.32) \\
0.33(0.59)\end{array}$ & $\begin{array}{l}2.51(0.37) \\
1.29(1.20)\end{array}$ & $\begin{array}{l}\mathrm{p}<0.0001^{\mathrm{a}} \\
\mathrm{NS}\end{array}$ \\
\hline \multicolumn{6}{|l|}{ VLDL } \\
\hline $\begin{array}{l}\text { Cholesterol } \\
\text { Triacylglycerols } \\
\text { Proteins }\end{array}$ & $\begin{array}{l}0.24(0.12) \\
0.67(0.65) \\
0.34(0.39)\end{array}$ & $\begin{array}{l}0.20(0.20) \\
0.54(0.36) \\
0.34(0.35)\end{array}$ & $\begin{array}{l}0.10(0.02) \\
0.30(0.26) \\
0.49(0.28)\end{array}$ & $\begin{array}{l}0.15(0.04) \\
0.47(0.52) \\
0.55(0.36)\end{array}$ & $\begin{array}{l}p<0.042^{b} \\
N S \\
N S\end{array}$ \\
\hline \multicolumn{6}{|l|}{ IDL } \\
\hline $\begin{array}{l}\text { Cholesterol } \\
\text { Triacylglycerols } \\
\text { Proteins }\end{array}$ & $\begin{array}{l}0.06(0.02) \\
0.25(0.19) \\
0.03(0.03)\end{array}$ & $\begin{array}{l}0.12(0.05) \\
0.41(0.35) \\
0.06(0.05)\end{array}$ & $\begin{array}{l}0.12(0.03) \\
0.23(0.21) \\
0.03(0.01)\end{array}$ & $\begin{array}{l}0.13(0.03) \\
0.42(0.45) \\
0.05(0.02)\end{array}$ & $\begin{array}{l}p<0.0001^{c} \\
N S \\
p<0.012^{d}\end{array}$ \\
\hline \multicolumn{6}{|l|}{ LDL } \\
\hline $\begin{array}{l}\text { Cholesterol } \\
\text { Triacylglycerols } \\
\text { Proteins }\end{array}$ & $\begin{array}{l}0.47(0.25) \\
0.12(0.08) \\
0.08(0.05)\end{array}$ & $\begin{array}{l}0.53(0.24) \\
0.08(0.11) \\
0.19(0.11)\end{array}$ & $\begin{array}{l}0.29(0.25) \\
0.05(0.04) \\
0.09(0.2)\end{array}$ & $\begin{array}{l}0.64(0.25) \\
0.11(0.13) \\
0.17(0.02)\end{array}$ & $\begin{array}{l}\mathrm{p}<0.003^{\mathrm{e}} \\
\mathrm{NS} \\
\mathrm{p}<0.0001^{\mathrm{f}}\end{array}$ \\
\hline \multicolumn{6}{|l|}{$\mathrm{HDL}$} \\
\hline $\begin{array}{l}\text { Cholesterol } \\
\text { Triacylglycerols } \\
\text { Proteins }\end{array}$ & $\begin{array}{l}1.12(0.26) \\
0.13(0.20) \\
0.76(0.12)\end{array}$ & $\begin{array}{l}1.18(0.36) \\
0.07(0.04) \\
0.89(0.21)\end{array}$ & $\begin{array}{l}0.43(0.05) \\
0.08(0.05) \\
1.32(0.19)\end{array}$ & $\begin{array}{l}1.24(0.14) \\
0.11(0.08) \\
0.81(0.08)\end{array}$ & $\begin{array}{l}\mathrm{p}<0.0001^{\mathrm{g}} \\
\mathrm{NS} \\
\mathrm{p}<0.0001^{\mathrm{h}}\end{array}$ \\
\hline \multicolumn{6}{|l|}{ Serum/HDL } \\
\hline Cholesterol ratio & $0.04(0.01)$ & $0.05(0.01)$ & $0.06(0.01)$ & $0.05(0.01)$ & NS \\
\hline \multicolumn{6}{|l|}{ LDL/HDL } \\
\hline Cholesterol ratio & $0.01(0.01)$ & $0.01(0.01)$ & $0.01(0.01)$ & $0.01(0.01)$ & NS \\
\hline
\end{tabular}

a Oestrogen group significantly differs from all other groups $(p<0.05)$. Luliberin analogue group significantly differs from control group $(p<0.05)$.

b Oestrogen group significantly differs from control group $(\mathrm{p}<0.05)$.

c Control group significantly differs from all other groups $(p<0.05)$.

d Orchidectomy group significantly differs from control and oestrogen groups $(p<0.05)$.

protein analysis was performed in each rat. Previous data do not permit comment on any association between lipoprotein profile and sex. On the contrary, age is a major factor in determining circulating lipoprotein levels (17).

Serum lipoprotein composition and laboratory methods in male Sprague-Dawley rats have been thoroughly reported $(13,16,19,21-27)$, although quantitative serum lipoprotein analysis in the Sprague-Dawley strain have barely been defined. The results described by De Pury et al. (18) and Lasser et al. (19) concur with ours, which differ from those obtained in other strains such as the Wistar (15) and Holtzman (20).

In animals, the largest amount of cholesterol is carried by HDL (15) as we found in the Sprague-Dawley strain $(50 \%)$. Also, we observed that total serum cholesterol is much lower than in humans, as well as LDL-cholesterol, which suggests that rats are probably not a good model c Luliberin analogue group significantly differ from control and oestrogen groups $(p<0.05)$. Orchidectomy group significantly differs from oestrogen group $(p<0.05)$.

f Orchidectomy and luliberin analogue groups significantly differ from control and oestrogen group $(p<0.05)$.

B Oestrogen group significantly differs from all other groups $(p<0.05)$.

h Oestrogen group significantly differs from all other groups $(p<0.05)$. Orchidectomy group significantly differs from control group $(p<0.05)$.

for studying atherogenic risk. This statement is confirmed by the atherogenic ratio (serum cholesterol/HDLcholesterol or LDL-cholesterol/HDL-cholesterol), which reflects the risk of cardiovascular disease $(28,29)$. In the present study serum cholesterol/HDL-cholesterol ratio was $1.93 \pm 0.40$, and LDL-cholesterol/HDL-cholesterol ratio was $0.41 \pm 0.18$. Since a serum cholesterol/ HDL-cholesterol ratio of 3.5 or less is considered optimal in humans and an indicator of low cardiovascular risk (30), it may in part explain why rats rarely suffer from atherosclerosis.

Orchidectomy has scarcely been studied in relation to lipoprotein profile in men with advanced prostatic carcinoma. Increases in serum cholesterol $(5,11,12)$, LDLapolipoprotein B (11) and serum and LDL-triacylglycerols (12) have been described. In rats, we observed an increase in IDL-cholesterol, IDL-proteins, HDL-proteins and LDL-proteins. In general, no great variations were 
noted compared with the control group. Perhaps the increase in LDL-apolipoprotein B may be consistent with a rise in the number of LDL particles, since each LDL particle contains only one apolipoprotein B. molecule (31), which leads to increased cardiovascular risk.

The influence of oestrogens on lipoprotein profiles has been widely studied and shows differences between the effects of endogenous and exogenous gonadal hormones, between men and pre and postmenopausal women, and depending on the composition and dosage of the hormone administered (6). Synthetic and conjugated oestrogens increase plasma VLDL and total triacylglycerols by enhancing their hepatic synthesis, particularly large VLDL particles which are directly catabolized by the liver rather than delipidated to small VLDL and LDL, and their elevation may thus be less atherogenic than other triacylglycerol-rich lipoproteins. A further main effect of oestrogens is to decrease LDL-cholesterol levels by increasing their clearance rate (increasing liver LDL receptors activity). Finally, the third most important effect of oestrogens is to raise HDL and HDL2-cholesterol and apolipoprotein A-I levels by inhibiting hepatic lipase activity (32-36). In the present study, decreases in serum cholesterol, VLDL-cholesterol, LDL-cholesterol (although without statistical significance) and HDL-cholesterol, together with increases in IDL-cholesterol and HDL-proteins have been observed in oestrogen treated rats compared with those of the control group.

Although no benefits were observed in the first large study of oestrogens and cardiovascular risk (37) with oestrogen therapy, the majority of other large studies conclude that oestrogen administration is associated with a reduced incidence of coronary heart disease and

\section{References}

1. Huggins C, Hodges CV. Studies in prostatic cancer I: the effect of castration, estrogen, and androgen injections on serum phosphatases in metastatic carcinoma of the prostate. Cancer Res $1941 ; 1: 293-7$.

2. Jacobi GH. Hormonal treatment of metastatic carcinoma of the prostate. In: Fitzpatrick JM, Krane RJ, editors. The Prostate. London: Churchill Livingstone Inc.-Longman Group UK Ltd., 1989:389-99.

3. Byar DP. The VACURG studies of cancer of the prostate. Cancer 1973; 32:1126-30

4. De Voogt HJ, Smith PH, Pavone-Macaluso M. Cardiovascular side-effects of diethylstilbestrol, cyproterone acetate, medroxyprogesterone acetate and estramustine phosphate used for the treatment of advanced prostatic cancer: results from the EORTC trials 30761 and 30762. J Urol 1986; 135:303-7.

5. Rössner S, Hedlund PO, Jogestrand T. Treatment of prostatic cancer: effects on serum lipoproteins and the cardiovascular system. J Urol 1985; 133:53-7.

6. Van Keep PA, Kopera H, editors. Oral Contraceptives and Lipoproteins. Geneva: Workshop conference in Hawaii. International Health Foundation, 1983. cardiovascular mortality (38-40). A similar lipoprotein profile is found in men with prostatic carcinoma following oestrogen therapy $(5,11,12,41)$.

Luliberin analogues have recently been introduced as a therapy for androgen deprivation in prostatic carcinoma, but their effects on lipoprotein profiles still have scarcely been investigated. Moorjani et al. $(10,11)$ have published two controversial, non-prospective and nonrandomized studies, which showed increases in HDLcholesterol and apolipoprotein A-I, with raised serum cholesterol in the former and no changes in serum cholesterol in the latter. On the other hand, Paisey et al. (9) have reported no changes in lipoprotein profiles and Gillatt et al. (42) have described an increase in total cholesterol levels. Therefore, the effects of luliberin analogues on cardiovascular risk remains controversial. Using luliberin analogues in rats, we have observed increases in serum cholesterol, LDL-cholesterol, IDL-cholesterol and LDL-proteins compared with the control group, which represents a non-favorable lipoprotein profile in terms of cardiovascular risk.

Finally, the increase in IDL-cholesterol observed in all treatment groups compared with control group was remarkable, since recent studies point to the atherogenic properties of IDL particles in humans, instead of triacylglycerol-rich particles (36).

\section{Acknowledgement}

Supported by grants from the "Fondo de Investigaciones Sanitarias de la Seguridad Social" (FIS 0624/91) and "Institut Municipal d'Investigacions Mèdiques" (IMIM-Project 1642490).

We thank Miss Christine O'Hara for her contribution to the preparation of the manuscript.

7. Schally AV, Comaru-Schally AM, Redding TW. Antitumour effects of analogues of hypothalamic hormones in endocrinedependent cancers. Proc Soc Exp Biol Med 1984; 175:25981 .

8. Conn PM, Crowley WF. Gonadotropin-releasing hormone and its analogues. N Engl J Med 1991; 324:93-103.

9. Paisey RB, Kadow C, Bolton D. Effects of cyproterone acetate and a long acting LHRH analogue on serum lipoproteins in patients with carcinoma of the prostate. J Royal Soc Med 1986; 79:210-1.

10. Moorjani S, Dupont A, Labrie F. Increase in plasma high-density lipoprotein concentration following complete androgen blockage in men with prostatic carcinoma. Metabolism 1987; 36:244-50.

11. Moorjani S, Dupont A, Labrie F. Changes in plasma lipoproteins during various androgen suppression therapies in men with prostatic carcinoma: effects of orchiectomy, estrogen, and combination treatment with luteinizing hormone-releasing hormone agonist and flutamide. J Clin Endocrinol Metab 1988; 
12. Aro J, Haapiainen R, Sanc T. Effects of orchiectomy and polyestradiol phosphate therapy on serum lipoprotein lipids and glucose tolerance in prostatic cancer patients. Eur Urol 1990; 17:229-35.

13. Chapman M J. Animal lipoproteins: chemistry, structure, and comparative aspects. J Lipid Res 1980; 21:789-853.

14. Mills GL, Taylaur CE. The distribution and compositions of serum lipoproteins in eighteen animals. Comp Biochem Physiol 1971; 40B:489-501.

15. Rubio-Martin MJ. Estudio comparativo de las lipoproteinas y receptor LDL en una población humana de diferentes edades $y$ varias especies animales [Doctoral Thesis]. Madrid, Universidad Complutense, 1990.

16. Camejo G. Structural studies of rat plasma lipoproteins. Biochemistry $1967 ; 6: 3228-3241$.

17. Schonfeld G, Felski C, Howald MA. Characterization of the plasma lipoproteins of the genetically obese hypcrlipoproteinemic Zucker fatty rats. J Lipid Res 1974; 15:457-64.

18. De Pury GG, Collins FD. Composition and concentration of lipoproteins in the serum of normal rats and rats deficient in essential fatty acids. Lipids 1972; 7:225-8.

19. Lasser NL, Roheim PS, Edelstein D, Eder HA. Serum lipoproteins of normal and cholesterol-fed rats. J Lipid Res 1973; 14:1-8.

20. Ontko JA, Wang ChS. Elevation of liver diacylglycerols and molecular species of diacylglycerols in rats fed in lipogenic diet. J Lipid Res 1989; 30:691-700.

21. Koga S, Horwitz DL, Scanu AM. Isolation and properties of lipoproteins from normal rat plasma. J Lipid Res 1969; 10:577-89.

22. Fainaru $M$, Havel RJ, Imaizumi K. Apoprotein content of plasma lipoproteins of the rat separated by gel chromatography or ultracentrifugation. Biochem Med 1977; 17:347-55.

23. Johanson MBN, Karlsson BW. Lipoproteins in serum of rat, mouse, gerbil, rabbit, pig and man studied by electrophoretical and immunological methods. Comp Biochem Physiol 1976; 45B:495-500.

24. Herbert PN, Windmueller HG, Bersot TP, Shulman RS. Characterization of the rat apolipoproteins. J Biol Chem 1974; 249:5718-28.

25. Windler E, Chao Y, Havel RJ. Regulation of the hepatic uptake of triglyceride-rich lipoproteins in the rat. J Biol Chem 1980; 255:8303-7.

26. Windler E, Havel RJ. Inhibitory effects of $C$ apolipoproteins from rats and humans on the uptake of triglyceride-rich lipoproteins and their remnants by the perfused rat liver. $J$ Lipid Res 1985; 26:556-65.

27. Weisgraber $\mathrm{KH}$, Mahley RW, Assmann G. The rat argininerich apoproteins and its redistribution following injection of iodinated lipoproteins into normal and hypercholesterolemic rats. Atherosclerosis 1977; 28:121-40.

28. Kannel WB, Castelli WP, Gordon T, McNamara PM. Serum cholesterol, lipoproteins and risk of coronary heart disease: the Framingham study. Ann Intern Med 1971; 74:1-12.
29. Castelli WP, Doyle JT, Gordon T, Hanes CG, Hjortland MC, Hulley SB et al. HDL cholesterol and other lipids in coronary heart disease. The cooperative lipoprotein phenotyping study. Circulation 1977; 55:767-72.

30. Keys A. Coronary heart disease in seven countries. Circulation 1970; 41(1):1-211.

31. Havel RJ, Kane JP. Structure and metabolism of plasma lipoproteins. In: Scriver CR, Beaudet AL, Sly WS, Valle D, editors. Metabolic basis of inherited disease. New York: MacGraw-Hill, 1989:1129-38.

32. Applebaum-Bowden D, McLean P, Steinmetz A, Fontana D, Matthys C, Warnick GR et al. Lipoprotein, apolipoprotein, and lipolytic enzyme changes following estrogen administration in postmenopausal women. J Lipid Res 1989; 30:1895-906.

33. Matthews KA, Meilahn E, Kuller LH, Kelsey SF, Caggiula AW, Wing RR. Menopause and risk factors for coronary heart disease. N Engl J Med 1989; 321:641-6.

34. Walsh BW, Schiff I, Rosner B, Greenberg L, Ravnikar V, Sacks FM. Effects of postmenopausal estrogen replacement on the concentrations and metabolism of plasma lipoproteins. $\mathrm{N}$ Engl J Med 1991; 325:1196-204.

35. Hong MK, Romm PA, Reagan K, Green CE, Rackley CE. Effects of estrogen replacement therapy on serum lipid values and angiographically defined coronary artery disease in postmenopausal women. Am J Cardiol 1992; 69:176-8.

36. Nabulsi AA, Folsom AR, White A, Patsch W, Heiss G, Wu $\mathrm{KK}$. Association of hormone-replacement therapy with various cardiovascular risk factors in postmenopausal women. $\mathrm{N} \mathrm{Engl}$ J Med 1993; 328:1068-75.

37. Wilson PWF, Garrison RJ, Castelli WP. Postmenopausal estrogen use, cigarette smoking, and cardiovascular morbidity in women over 50. The Framingham study. N Engl J Med 1985; 313:1038-42.

38. Stampfer MJ, Willet WC, Colditz GA, Rosner B, Speizer FE, Hennekens $\mathrm{CH}$. A prospective study of postmenopausal estrogen therapy and coronary heart disease. N Engl J Med 1985; 313:1044-9.

39. Colditz GA, Willet WC, Stampfer MJ, Rosner B, Speizer FE, Hennekens $\mathrm{CH}$. Menopause and the risk of coronary heart disease in women. $\mathrm{N}$ Engl $\mathrm{J}$ Med 1987; 316:1105-10.

40. Stampfer MJ, Colditz GA, Willet WC, Manson JE, Rosner B, Speizer FE et al. Postmenopausal estrogen therapy and cardiovascular disease. Ten-year follow-up from the Nurses' Health Study. N Engl J Med 1991; 325:756-62.

41. Bulus NV, Lewis SB, Das S, Clayton WE. Serum lipid changes after estrogen therapy in prostatic carcinoma. Urology 1982; 20:147-50.

42: Gillatt DA, Bolton CH, Chadwick D, Downs LG, Hopton MI, Gingell JC. Lipoprotein levels following treatment with cyproterone acetate or LHRH analogues. $\mathrm{Br} \mathrm{J}$ Urol 1993; 71:728-30.

Carles Lladó Carbonell

C/Calabria, $150,6^{\circ} 3^{\circ}$

E-08015 Barcelona

Spain 
. 